Maciej Kokoszko (Łódź)

Krzysztof Jagusiak (Łódź)

Jolanta Dybała (Piotrków Trybunalski)

\title{
The Chickpea (épéßıv9oc; Cicer arietinum L) as a Medicinal Foodstuff and Medicine in Selected Greek Medical Writings
}

\section{Introduction}

T eguminous plants, referred to as óspria (öorpıa) in Greek, were a crucially Limportant element in the Mediterranean diet since time immemorial ${ }^{1}$, as is evidenced in research concerning their role as a foodstuff ${ }^{2}$. As such, these plants were second only to cereals ${ }^{3}$ and so they were in the early Middle Ages, as is

${ }^{1}$ C. Perlès, Les stratégies alimentaires dans les temps préhistoriques, [in:] Histoire de l'alimentation, ed. J.-L. Flandrin, M. Montanari, Paris 1996, p. 42 (lentils).

${ }^{2}$ Cereals, especially wheat, formed the basis of the diet throughout the period under scrutiny. For antiquity, see for instance: F. BRAUdeL, La Méditerranée et le monde méditerranéen à l'époque de Philippe II, vol. I, Paris 1966, p. 215; M.-C. Amouretri, Villes et campagnes grecques, [in:] Histoire de..., p. 133-150; C. Grottanelli, La viande et ses rites, [in:] Histoire de..., p. 117-118 (bread versus meat); G. Sassatelli, L'alimentation des Étrusques, [in:] Histoire de..., p. 184-186; P. Garnsey, Food and society in classical antiquity, Cambridge 2002, p. 12-19, see in particular p. 18, 119-121; J.M. Wilkins, P. Hill, Food in the ancient world, Oxford 2006, p. 113-139, especially p. 11 (general conclusions), p. 120. For the Byzantine period, see: $\mathrm{PH}$. Koukoules, Byzantinon bios kai politismos, vol. V, Hai trofai kai ta pota..., Athènes 1952, passim, especially p. 12-35; E. KIsLINGER, Les chrétiens d'Orient: règles et réalités alimentaires dans le monde byzantin, [in:] Histoire de ..., p. 327-332, 337-430; J.-C. Cheynet, La valeur marchande des produits alimentaires dans l'Empire byzantin, [in:] Byzantinon diatrohi kai mageireiai. Praktika imeridas "Peri tis diatrophis sto Byzantio". Food and cooking in Byzantium. Proceedings of the symposium "On food in Byzantium". Thessaloniki Museum of Byzantine Culture 4 November 2001, ed. D.D. Papanikola-Bakirtzi, Athens 2005, p. 35-39; J. Koder, I kathemerini diatrophi sto Byzantio me basi tis piges, [in:] Byzantinon diatrohi kai..., p. 19-21; IDEM, Stew and salted meat - opulent normality in the diet of every day?, [in:] Eat, drink and be merry (Luke 12:19). Food and wine in Byzantium. In honour of Professor A.A.M. Bryer, ed. L. Brubaker, K. Linardou, Aldershot 2007, p. 65-66, 72; D. StathaKopoulos, Between the field and the plate: how agricultural products were processed into food, [in:] Eat, drink..., p. 114; C. Bourbou, Health and disease in Byzantine Crete $\left(7^{\text {th }}-12^{\text {th }}\right.$ centuries $\left.A D\right)$, Farnham-Burlington 2010, p. 128; M. Kокоszко, Smaki Konstantynopola, [in:] Konstantynopol - Nowy Rzym. Miasto i ludzie w okresie wczesnobizantyńskim, ed. M.J. LeszKA, T. WolińsKa, Warszawa 2011, p. 474-485, especially p. 474 (general considerations).

${ }^{3}$ There is an extensive bibliography concerning the role of leguminous plants in the ancient diet, see for example: J. ANDré, L'alimentation et la cuisine à Rome, Paris 1961, p. 35-42 (the diet of the 
illustrated in the research of such historians as Phaedon Koukoules ${ }^{4}$, Johannes Koder ${ }^{5}$, Andrew Dalby ${ }^{6}$, Marcus Louis Rautman ${ }^{7}$ or Ilias Anagnostakis ${ }^{8}$.

Research indicates that these plants were domesticated early in history and were widely cultivated. Their use was not limited to the domesticated varieties, but included also wild-growing types, although these were regarded as having slightly different properties. In the timeframe under consideration, that is from the fourth century $\mathrm{BC}$ to the seventh century $\mathrm{AD}$, they were a crucially important staple in the diet. In the context of this inquiry, it is also important to note that according to medical writings preserved from antiquity and the early Byzantine period leguminous plants were considered to be an accessible source of substances which could

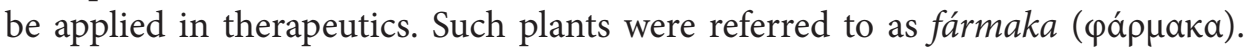
One of the most commonly mentioned leguminous plants was the chickpea (Cicer

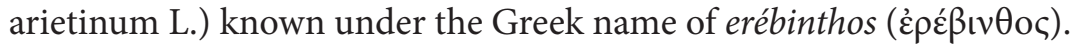

Romans); L. Foxhall, H.A. Forbes, Sitomereia: the role of grain as staple food in classical antiquity, Chi 12, 1982, especially p. 41-2, 89-90; P. DAR, Food and archeology in Romano-Byzantine Palestine, [in:] Food in antiquity, ed. J. Wilkins, D. Harvey, M. Dobson, Exeter 1995, p. 328, 330-331 (Palestine in the early imperial period); V. Nutton, Galen and the traveler's fare, [in:] Food in..., p. 360, 364 (Galen's remarks on the consumption of leguminous plants in Egypt); M.-C. AMOURETTI, Villes..., p. 139, 143 (the diet of the Greeks); E. Bresciani, Nourritures et boissons de l'Égypte ancienne, [in:] Histoire de..., p. 66 (Egypt); G. Sassatelli, L'alimentation..., p. 186-187 (Etruscans); A. Spanò Giammellaro, Les Phéniciens et les Carthaginois, [in:] Histoire de..., p. 87 (Phoenicians); K.B. Flint-Hamilton, Legumes in ancient Greece and Rome: food, medicine or poison, He 68, 1999, p. 371-385 (its role as a foodstuff and a medicine); P. GARnsey, Food..., p. 20-21, 37-38 (its role in the diet in antiquity); A. DALBY, Food in the ancient world from A to Z, London-New York 2003, p. 194; J.P. ALCOCK, Food in the ancient world, Westport-London 2006, p. 14-15, 35-38 (the characteristics of the most important leguminous plants in antiquity); J.M. WiLKINs, P. HiLl, Food..., p. 112-139 (the role of cereals and leguminous plants in the diet); A. DALBY, The flavours of classical Greece, [in:] Flavours and delights. Tastes and pleasures of ancient and Byzantine cuisine, ed. I. ANAGNOSTAKIs, Athens 2013, p. 19 (lentils as a staple food of the Greeks).

${ }^{4}$ PH. Koukoules, Byzantinon trophai kai pota, EEB $\Sigma$ 17, 1941, p. 70-71; IDEM, Byzantinon bios..., p. 96-97.

${ }^{5}$ J. KodER, I kathemerini..., p. 23; IDEM, Stew and..., especially p. 61, 67, 69-70; IDEM, Everyday food in the middle Byzantine period, [in:] Flavours and..., p. 141, 149.

${ }^{6}$ A. Dalby, Flavours of Byzantium, Totnes 2003, p. 80-81.

${ }^{7}$ M.L. Rautman, The daily life in the Byzantine Empire, Westport-Oxford 2006, p. 252.

${ }^{8}$ I. Anagnostakis, Pallikaria of lentils. The "brave boys" of beans, [in:] Flavours and..., p. 133-137; IDEM, "The raw and the cooked": ways of cooking and serving food in Byzantium, [in:] Flavours and..., p. 175-176, 180-181. See also: M. Koкoszko, Smaki..., p. 485-487; M. Koкоszko, Ł. ErLich, Rola roślin strączkowych (ỏotpıa) $w$ diecie późnego antyku i wczesnego Bizancjum (IV-VII w.) na podstawie wybranych źródeł, ZW 17, 2012, p. 8-18; M. Koкoszko, Z. RzeźNickA, K. JAGusiak, Rola roślin strączkowych (óspria) w świetle źródeł medycznych pomiędzy II a VII w., [in:] Dietetyka i sztuka kulinarna antyku i wczesnego Bizancjum (II VII w.), vol. II, Pokarm dla ciała i ducha, ed. M. Koкоszко, Łódź 2014, p. 67-75; M. Кокоszко, J. DyваєA, K. Jagusiak, Z. Rzeźnicka, Dieta mnichów syryjskich. Komentarz do terminu ospria (ö $\sigma \pi \rho \iota \alpha) w$ Historia religiosa Teodoreta $z$ Cyru, BPT 7, 2014, p. 115-143; IDEM, Dieta monastyczna w świetle nauki medycznej. Teodoret $z$ Cyru i medycy o soczewicy, VP 34, 2014, p. 297-329. 
The study at hand aims to present the views of Greek medicine concerning this plant in the period under discussion (fourth century BC - seventh century AD) by concentrating on its dietary role, pharmacological properties and therapeutic uses. The reason for this selection is due to the fact that this particular branch of knowledge was developed primarily by Greek medical doctors.

\section{The dietary-pharmacological characteristics of the chickpea}

The views on the properties of the chickpea evolved over centuries. It was described as early as in the fourth century BC in the work titled De diaeta, where it was characterized as laxative, diuretic and nutritious ${ }^{9}$, and included into the category of kathartic substances ${ }^{10}$.

Athenaeus of Naucratis wrote that Diocles of Carystus (late fourth or early third century BC) believed in its warming qualities and the ability to attract (the matter deeply ingrained in tissues) ${ }^{11}$; reportedly, he also estimated that the white chickpea is more powerful than the black, much in the same way as the green and the Milesian is more powerful than the kriós (кpı́s) chickpea, or that soaked is more potent than dried $^{12}$. It has to be emphasized that it was at such an early date that this plant was regarded as being a phármakon, which is evidenced in a letter by Diocles discussing the prophylactic approaches to various diseases preserved in the seventh-century medical encyclopaedia compiled by Paul of Aegina. The author recommended drinking a chickpea decoction as one of the basic therapeutic

\footnotetext{
${ }_{9}^{9}$ Hippocratis de diaeta, 45, 5-7, ed. R. Joly, S. ByL, Berlin 2003 (cetera: De diaeta).

${ }^{10}$ De diaeta, 54, 49-52.

${ }^{11}$ The interpretation presented in this paper is based on a translation different from that proposed by K. Bartol and J. Danielewicz (Atenajos, Uczta mędrców, trans., ed. K. Bartol, J. Danielewicz, Poznan 2010, p. 166). From our point of view, Diocles cannot have suggested that the chickpea 'triggered fermentation processes in the body. The later medical writings do not support this observa-

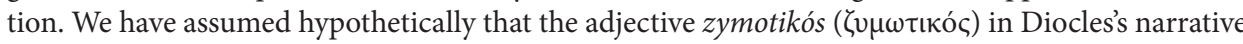
is used with a different meaning and does not imply that the given substance was regarded as an acidifying or fermenting agent. This assumption has been made on two accounts: first, as illustrated in this article, the views of medical writers were very consistent from antiquity to the Byzantine period, and second, Diocles himself seems to remain perfectly in line with other physicians (he documented the use of this medicament for ailments mentioned in the later medical writings). This semantic aspect may be explained by considering the description of zyme ( $\left.\hat{u}_{\mu \eta}\right)$ in the De materia medica by Dioscorides, where leaven/yeast is described as having the ability to warm up and attract, much in the same way as may be found in the descriptions of the chickpea - Pedanii Dioscuridis Anazarbei De materia medica libri quinque, II, 85, 2, 5-8, ed. M. Wellmann, vol. I-III, Berolini 1906-1914 (cetera: Dioscurides, De materia medica). It appears that the adjective zymotikós should be translated differently, in line with the statement of Diocles, who believed that the chickpea is similar to zýme in its functioning, i.e. in being a warming agent and having the ability to attract fluids from deep down in the body.

${ }^{12}$ Athenaei Naucratitae dipnosophistarum libri XV, II, 55b (44, 44-48 KaIBEL), rec. G. KaIBEL, vol. I-III, Lipsiae-Berolini 1887-1890 (cetera: Athenaeus of Naucratis, Deipnosophistae).
} 
devices in curing gastric problems ${ }^{13}$. On the other hand, for dealing with malfunctions of urinary system, he advised to drink water used for soaking chickpea beans mixed with some wine ${ }^{14}$. In Athenaeus' Deipnosophistae we also find a remark that Diphilus of Siphnus (the first half of the third century BC) characterized the chickpea as difficult to digest, detoxifying, diuretic and carminative ${ }^{15}$. All of the above properties are mentioned in later writings dealing with the plant, which supports the claim that the medical theory concerning this issue at the turn of the fourth and the third centuries was fairly advanced.

But the fully developed set of views related to the chickpea appeared only in the first century $\mathrm{AD}$, which is accredited to Dioscorides and his De materia medica. His discussion of the subject is relatively extensive and detailed. The author knew of two basic varieties of erébinthos ${ }^{16}$ : one was domesticated - with two subvarieties, orobías (ỏpoßíac) and kriós ${ }^{17}$ - whereas the other grew in the wild ${ }^{18}$. The treatises of the doctor of Anazarbos demonstrate that the main part of the plant used as a pharmacological ingredient was the beans (or a bean-based decoction). Roots and leaves were used to a much lesser degree, but were applied both in internal as well as external use (most often in the form of cataplasms) ${ }^{19}$.

The first observation concerning the dietary-pharmacological characteristics of the chickpea included in Dioscorides' work emphasizes its beneficial effects on the digestive system and the formation of urine, but also mentions that it causes flatulence ${ }^{20}$.

${ }^{13}$ Paulus Aegineta, I, 100, 1, 1-6, 28, ed. I.L. Heiberg, vol. I-II, Lipsiae-Berolini 1921-1924 (cetera: Paul of Aegina, Epitome; the fragment on gastric problems - I, 100, 4, 1-17; the chickpea - I, 100, $4,13-14)$.

${ }^{14}$ Paul of Aegina, Epitome, I, 100, 5, 1-14 (the chickpea - I, 100, 5, 9-10).

${ }^{15}$ Athenaeus of Naucratis, Deipnosophistae, II, 55b (44, 43-44 Kaibel).

${ }^{16}$ A passage concerning the plant - Dioscurides, De materia medica, II, 104, 1, 1-2, 11.

${ }^{17}$ The author seems to suggest that both varieties, orobías and kriós, were domesticated.

${ }^{18}$ In his Euporista vel de simplicibus medicinis, he distinguishes between the white and the black variety, without proposing any links between these two classifications. For the black and the white chickpea, see Pedanii Dioscuridis Anazarbei Euporista vel de simplicibus medicinis, II, 58, 2, 7, [in:] Pedanii Dioscuridis Anazarbei De materia medica libri quinque, ed. M. Wellmann, vol. III, Berlin 1914 (cetera: Dioscorides, Euporista vel de simplicibus medicinis). A link, however, existed and we know it from the work of Galen, who wrote that the black variety (with its characteristically small beans) was grown in Bithynia and called kriós. It was regarded as a highly effective remedy for renal calculi and administered to patients in the form of a decoction - Galeni De alimentorum facultatibus libri III, 533, 12-16, [in:] Claudii Galeni opera omnia, ed. D.C.G. KüHN, vol. VI, Lipsiae 1823 (cetera: Galen, De alimentorum facultatibus). It follows that the other variety, i.e. orobias, should be identified with the brightly coloured chickpea.

${ }^{19}$ See below.

${ }^{20}$ The latter of the analysed treatises of Dioscorides includes the chickpea (and a chickpea-based

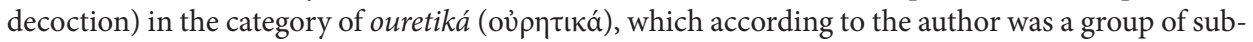
stances administered to people suffering from urinary problems resulting from the calculi formed in their urinary system. It was also used as a supplementary remedy for hydrops and jaundice - Dioscorides, Euporista vel de simplicibus medicinis, II, 119, 1, 1-5, 10 (the chickpea and the decoction - II, 119, 4, 1). 
In addition to that, the plant gives the skin a proper colouring ${ }^{21}$, induces menstruation, accelerates childbirth ${ }^{22}$ and facilitates lactation ${ }^{23}$. The doctor of Anazarbus also believed that both orobías and kriós were highly effective diuretic agents and argued that for this reason a chickpea decoction seasoned with rosemary was used as a cure for jaundice ${ }^{24}$ and hydrops ${ }^{25}$ (even though, as he admitted, this medicine was damaging to ulcerated bladders and kidneys ${ }^{26}$. The author observed that the leaves of domesticated and wild varieties of the chickpea are similar in shape. Despite its pungent smell and the fact that its fruit was slightly different from that of the varieties found in agriculture ${ }^{27}$, the medicinal properties of all these varieties were virtually identical ${ }^{28}$.

Galen (second century $\mathrm{AD}$ ) wrote even more extensively on the subject. The characteristics included in his De alimentorum facultatibus is primarily concerned with the dietary qualities of the plant, while a list of pharmacological uses is given in the De simplicium medicamentorum temperamentis ac facultatibus. The description of the plant in the former treatise begins with the statement that the chickpea is no less carminative than broad beans, but is far more nutritious ${ }^{29}$. At the time it was used to arouse sexual desire and stimulate the production of semen; for this reason it was administered to male horses before mating. Galen also wrote that it had a litholytic effect, much more powerful than broad beans, and as such it was used in crushing kidney stones (the kriós variety with its characteristically small black beans was particularly used to this end; Galen recommended that a decoction based on these beans ${ }^{30}$ should be given to people suffering from renal calculi). The

\footnotetext{
${ }^{21}$ Boiled chickpeas appear on the list of foodstuffs having a beneficial effect on the skin, Dioscorides, Euporista vel de simplicibus medicinis, I, 105, 1, 1-3 (the chickpea - I, 105, 1, 1).

${ }^{22}$ The same application was discussed in the other work by Dioscorides. It should be noted that both remedies were qualified as highly effective - DIOsCORIDEs, Euporista vel de simplicibus medicinis, II, $79,1,1-80,3,5$ (the chickpea, the decoction - II, 80, 3, 2-3).

${ }^{23}$ Dioscurides, De materia medica, II, 104, 1, 1-3. Consequently, the chickpea appears also in the Euporista vel de simplicibus medicinis as a foodstuff particularly effective in inducing lactation - Dioscorides, Euporista vel de simplicibus medicinis, I, 130, 1, 1-2, 9 (the chickpea - I, 130, 1, 2). ${ }^{24}$ In the other treatise, Dioscorides reported that both the black and the white lentils (and a lentilsbased decoction) were used as a remedy for jaundice - Dioscorides, Euporista vel de simplicibus medicinis, II, 58, 1, 1-7, 8 (the chickpea - II, 58, 2, 7). He also noted that the treatment method included using a rosemary decoction administered with (boiled?) chickpeas after a walk, which was an integral part of the process of healing - Dioscorides, Euporista vel de simplicibus medicinis, II, $58,3,7$.

${ }^{25}$ In his Euporista vel de simplicibus medicinis Dioscorides wrote that boiled chickpeas were part of the diet which supplements the doctrine expounded in the De materia medica - Dioscorides, Euporista vel de simplicibus medicinis, II, 65, 1, 1-8, 8 (the chickpea - II, 65, 3, 4).

${ }^{26}$ Dioscurides, De materia medica, II, 104, 2, 1-4.

${ }^{27}$ The author, however, did not specify the nature of the difference.

${ }^{28}$ Dioscurides, De materia medica, II, 104, 2, 9-11.

${ }^{29}$ Described earlier in the text of the De alimentorum facultatibus.

${ }^{30}$ Galen, De alimentorum facultatibus, 533, 8-16.
} 
doctor of Pergamum noted that Unripe chickpeas were also used as a foodstuff and that their qualities were analogous to those of other plants before they were fully developed ${ }^{31}$. He also observed that chickpea beans were at times roasted (in a way similar to broad beans), which made them less carminative, but more difficult to digest; as such they impinged on the functioning of intestines. The discussion ends with a remark that roasted chickpeas produced a foodstuff characterized by dense fluids ${ }^{32}$.

The main pharmacological characteristics of the chickpea is contained in the De simplicium medicamentorum temperamentis ac facultatibus and supplements the information included in the De alimentorum facultatibus. In this treatise, Galen wrote about the carminative effects of the plant, but also about its nutritious value, positive impact on the digestive system and other properties, such as stimulating urination, lactation, production of semen and inducing menstruation. Also in this work the author emphasized that the kriós variety was the most effective diuretic agent: a decoction based on chickpea beans was supposed to have a powerful therapeutic effect in crushing renal calculi. The orobias variety in its turn was accredited with the ability to attract (the matter deeply ingrained in the body), diaphoretic, cutting and cleansing. The doctor also remarked that by its very nature the chickpea had warming and slightly desiccative effects, while its admixture of bitterness helped to detoxify the spleen, liver and kidneys. Besides, not only did it remove scabies, lichen planus and contusions, but also induced diaphoresis, which helped, for instance, in curing testicular lumps. When applied with an admixture of honey, it was believed to heal ulcerating wounds ${ }^{33}$. The wild variety was, in turn, deemed to be more effective than the domesticated varieties: for instance, it was supposed to have more powerful warming and desiccative effects and to be more piquant and bitter in taste ${ }^{34}$.

In the Collectiones medicae of Oribasius, the dietary and pharmacological features of the chickpea are mentioned at several instances, beginning with Book I., Book III, which contains a discussion of various classes of foodstuffs divided according to their dominant features, also includes some references to the chickpea. Further comments can be found in Books XIV and XV. The main dietary characteristics are included in Book I and are based on the doctrine of Galen as expounded in the De alimentorum facultatibus. Thus, we also find a discussion of the carminative effects and nutritious value, its aphrodisiac potential and the

\footnotetext{
${ }^{31}$ He does not explain the point any further at this particular instance, but later physicians must have understood his intention, since they mentioned, among other things, the capacity of the unripened beans to ensure appropriate hydration of the body.

${ }^{32}$ Galen, De alimentorum facultatibus, 534, 1-7.

${ }^{33}$ Galeni de simplicium medicamentorum temperamentis ac facultatibus libri XI, 876, 12 - 877, 5, vol. XI, [in:] Claudii Galeni opera omnia, ed. D.C.G. KüHN, vol. XI-XII, Lipsiae 1826-1827 (cetera: GALEN, De simplicium medicamentorum temperamentis ac facultatibus).

${ }^{34}$ Galen, De simplicium medicamentorum temperamentis ac facultatibus, 877, 6-9, vol. XI.
} 
ability to boost the production of semen as well as its role as a cleansing agent (particularly as a remedy for renal calculi) ${ }^{35}$. The work of Oribasius illustrates the popularity of the claims concerning the aphrodisiac qualities of the plant among medical doctors of the time. We find him quoting passages from the writings of Rufus of Ephesus (second century) containing a more detailed discussion of this issue and, as opposed to other authors, a physiological explanation of the phenomenon in question. The doctor believed that sexual prowess was boosted by flatulence resulting from having eaten a meal containing chickpeas. In the same passage we read that the carminative effect was mitigated by rue, which had a negative impact on the readiness for having $\operatorname{sex}^{36}$.

Book III provides the reader with analogous information to what we have discussed above, but contains some additional elements borrowed from Dioscorides and Galen which were not included in the main characteristics of the plant in Book I. Thus, we read that green chickpeas (that is unripened) were categorized as rich in indigestible moisture and as such included into the class perittomatiká $(\pi \varepsilon \rho \iota \tau \omega \mu \alpha \tau \iota \kappa \alpha))^{37}$. No wonder, then, that the plant was also included into the category of moisturising foodstuff ${ }^{38}$. The doctor classified the chickpea in the group of products containing the most important nutritious substances and agreed with Galen that it was more nourishing than broad beans ${ }^{39}$. Oribasius was sceptical

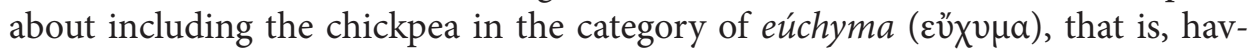
ing the ability to induce production of proper (that is well-balanced) humours on account of its taste and smell. On the other hand, he did not consider the plant

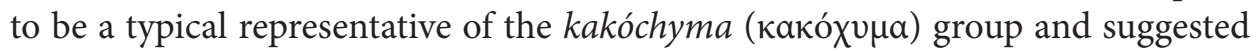
that in this respect it did not bring about extremely detrimental effects ${ }^{40}$. The plant appears also in the catalogue of foodstuffs which are difficult to digest ${ }^{41}$ and have carminative effects ${ }^{42}$. Finally, in Book III of Oribasius' writings, we see the author mentioning the cleansing features of the plant and emphasising the role of the black variety, particularly effective in this respect (above all, it helped in crushing renal calculi) ${ }^{43}$.

Other therapeutic qualities of the chickpea are discussed in Books XIV and $\mathrm{XV}$ of the Collectiones medicae. The characteristics may be inferred from Oribasius' discussion of the meaning of colours with regard to the substances used as

\footnotetext{
${ }^{35}$ Oribasii collectionum medicarum reliquiae, I, 20, 1, 1-3, 4, ed. I. RAEDER, vol. I-IV, Lipsiae-Berolini 1928-1933 (cetera: Oribasius, Collectiones medicae).

${ }^{36}$ Oribasius, Collectiones medicae, VI, 38, 1, 1-30, 5 (the quoted passage - VI, 38, 16, 4-7; the chickpea - VI, 38, 16, 5).

${ }^{37}$ Oribasius, Collectiones medicae, III, 11, 1, 16 (the chickpea - III, 11, 1, 1).

${ }^{38}$ Oribasius, Collectiones medicae, III, 34, 1, 1-8, 2 (the chickpea - III, 34, 7, 8).

${ }^{39}$ Oribasius, Collectiones medicae, III, 13, 1, 1-13, 2 (the chickpea - III, 13, 8, 1).

${ }^{40}$ Oribasius, Collectiones medicae, III, 16, 1, 1-18, 3 (the chickpea - III, 16, 8, 2).

${ }^{41}$ Oribasius, Collectiones medicae, III, 18, 1, 1-13, 1 (the chickpea - III, 18, 11, 2).

${ }^{42}$ Oribasius, Collectiones medicae, III, 23, 1, 1-9, 4 (the chickpea - III, 23, 1, 1).

${ }^{43}$ Oribasius, Collectiones medicae, III, 24, 1, 1-16, 7 (the chickpea - III, 24, 1, 2-3).
} 
nourishment or medicine. For instance, yellow and red substances were believed to be more warming than those of white colouring. It has to be noted that erébinthos was mentioned as an example of foodstuffs characterized by intense and warm colouring ${ }^{44}$. This conclusion is confirmed further in the same book, where the author enumerates warming substances without discriminating between various degrees of warming capacity ${ }^{45}$.

The chickpea (domesticated as well as the wild-growing varieties) was includ-

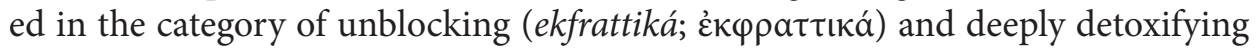

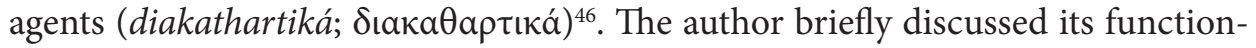
ing towards the end of the chapter and explained that medicaments of this sort mitigate the negative effects of viscous and thick humours. They were believed to be particularly helpful in diluting and releasing the noxious substances present in the chest and lungs; also, they were used in unblocking the liver and restoring the proper functioning of the spleen ${ }^{47}$.

The chickpea, particularly the kriós variety, was included in the category

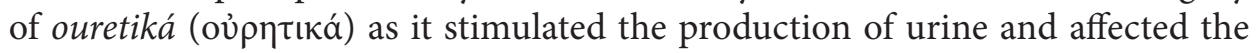
urinary system in a number of ways ${ }^{48}$. It is worth mentioning that this classification is repeated in a passage borrowed by Oribasius from Zopyrus (second - first century BC), who described the plant as particularly effective (especially orobías, the white variety) in releasing noxious substances from kidneys ${ }^{49}$. To remove all doubts concerning the position of the chickpea as the most effective agent used for purifying kidneys, the author of Collectiones medicae discussed the subject once more, this time drawing on the work of Galen. The doctor of Pergamum attributed to the chickpea not only detoxifying, but also lytic qualities, which meant that in addition to crushing renal calculi it helped to excrete them from the body together with urine ${ }^{50}$.

Following Galen, Oribasius mentions the chickpea (domesticated and wildgrowing) in a passage in Book XIV, while discussing the substances which attract fluids to the surface of the body (helktiká; $\dot{\varepsilon} \lambda \kappa \tau$ $\kappa_{\alpha}$ ) or work in the opposite direc-

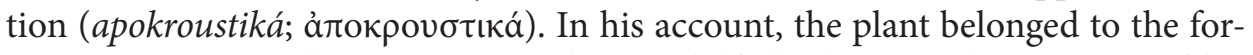
mer category. On this occasion Oribasius skilfully drew on the writings of his predecessor $^{51}$ and went into greater detail in discussing the characteristics of

\footnotetext{
${ }^{44}$ Oribasius, Collectiones medicae, XIV, 7, 1, 1-3, 5 (the chickpea - XIV, 7, 2, 2).

${ }^{45}$ Oribasius, Collectiones medicae, XIV, 14, 1, 1-17, 2 (the chickpea - XIV, 14, 9, 4).

${ }^{46}$ Oribasius, Collectiones medicae, XIV, 47, 1, 1-3, 4 (the chickpea - IV, 47, 1, 6).

${ }^{47}$ Oribasius, Collectiones medicae, XIV, 47, 2, 1-3, 4.

${ }^{48}$ Oribasius, Collectiones medicae, XIV, 49, 1, 1-12, 4 (the chickpea - XIV, 49, 1, 9-10).

${ }^{49}$ OrIbasius, Collectiones medicae, XIV, 50, 1, 1-3, 4 (the passage on detoxifying the kidneys - XIV, $50,3,1-4$; the chickpea - XIV, 50, 3, 4).

${ }^{50}$ Oribasius, Collectiones medicae, XIV, 53, 1, 1-2, 5 (the chickpea - XIV, 53, 2, 4).

${ }^{51}$ Oribasius reworked the relevant fragments of the De simplicium medicamentorum temperamentis ac facultatibus in an innovative way. He expanded the doctrine of Galen by including substances with these properties - among them, he mentioned both the wild-growing and the domesticated chickpea.
} 
this sort of substances. He argued that all helktiká, by their very nature, have warming qualities and are composed of small particles. It is their warmth that has the ability to attract, while the particle-based composition of these substances makes it a more powerful warming agent $t^{52}$. Still referring to Galen, the doctor of emperor Julian discussed the medicine's stimulating or impeding the production of semen. He included the chickpea to the former class, because, as he explained, semen was produced from the usable food remainders ( $\dot{\varepsilon} \kappa \chi \rho \eta \sigma \tau o \tilde{v} \pi \varepsilon \rho \iota \tau \tau \dot{\omega} \mu \alpha \tau o \varsigma)$ and the plant on account of being carminative and nutritious supplied such useful substances $^{53}$. In Book XV of the Collectiones medicae, the doctor no longer referred to Galen's writings in presenting the main dietary-pharmacological characteristics of the chickpea and instead chose the De materia medica by Dioscorides in a slightly simplified version ${ }^{54}$. There is no need to discuss it further as it has been already quoted in its original form.

The description of the chickpea contained in the work of the sixth-century medical doctor Aetius of Amida is based directly on Oribasius. The main dietarypharmacological characteristics do not differ from that of the author of Collectiones medicae, which means that the description was rooted in the doctrine of Dioscorides ${ }^{55}$. Book I of his encyclopaedia preserves the considerations concerning the relationship between the warming qualities of foodstuffs and their colour, which generally indicate that the chickpea was regarded as a warming agent ${ }^{56}$. The dietary qualities of the plant are systematically mentioned in Book II of the Iatricorum libri, where Aetius of Amida enumerates the various categories of substances grouped according to their dominant feature. The chickpea is thus mentioned among foodstuffs which have warming qualities ${ }^{57}$, a considerable nutritious value ${ }^{58}$, carminative ${ }^{59}$ and detoxifying effects ${ }^{60}$ and, in the case of green chickpeas, work as a moisturising agent ${ }^{61}$.

\footnotetext{
${ }^{52}$ Oribasius, Collectiones medicae, XIV, 59, 1, 1-10, 2 (the chickpea - XIV, 59, 2, 3; the chickpea as a remedy from the helktiká group - XIV, 59, 1, 1-2,1).

${ }^{53}$ Oribasius, Collectiones medicae, XIV, 66, 1, 1-7, 6 (the quoted explanation - XIV, 66, 3, 6-4, 1; the chickpea - XIV, 66, 4, 1).

${ }^{54}$ He preserved all the most important features, but eliminated the passages which referred to specific diseases. Thus, we read that the domesticated chickpea has attractive, diaphoretic and cutting properties and is a moderately hydrating agent. The wild-growing variety is more powerful: warmer, rather dehydrating, more spicy and bitter - Oribasıus, Collectiones medicae, XV, 1:5, 28, $1-29,3$.

${ }^{55}$ Aetii Amideni libri medicinales I-VIII, I, 145, 1-8, ed. A. Olıvieri, Lipsiae-Berolini 1935-1950 (cetera: Aetius of Amida, Iatricorum libri).

${ }^{56}$ Aetius of Amida, Iatricorum libri, Prolegomena, 354-357.

${ }^{57}$ Aetius of Amida, Iatricorum libri, II, 198, 1-13 (the chickpea - II, 198, 10).

${ }^{58}$ Aetius of AmidA, Iatricorum libri, II, 250, 1-21 (the chickpea - II, 250, 13).

${ }^{59}$ Aetius of AmidA, Iatricorum libri, II, 259, 1-9 (the chickpea - II, 259, 1).

${ }^{60}$ Aetius of AmidA, Iatricorum libri, II, 260, 1-26 (the chickpea - II, 260, 2-3).

${ }^{61}$ Aetius of Amida, Iatricorum libri, II, 270, 1-5 (the chickpea - II, 270, 4).
} 
The pharmacological catalogues of Book II include additional information about the plant. According to the author, the chickpea was a relatively effective warming agent (its external cover, leaves and fruit were included in the second degree of effectiveness in this respect) ${ }^{62}$, had the ability to attract (the organic juices from deep down in the body) ${ }^{63}$ and stimulated the production of semen (due to its nutritious value as well as carminative and warming properties) ${ }^{64}$. Finally, he concluded that green (that is, unripe) chickpeas contained a fair amount of indigestible moisture and as such belonged to the group perittomatiká ${ }^{65}$.

The work of Paul of Aegina explicitly demonstrates the persistence of the dietary-pharmacological doctrine developed in antiquity. A brief dietary characteristic with some elements of pharmacological description is contained in Book I of his work, in the chapter devoted to all leguminous plants ${ }^{66}$. The main description of the plant can be found in Book VII of his encyclopaedia and is in line with the canon of classical and Byzantine medicine ${ }^{67}$.

\section{The therapeutic uses of the chickpea}

In discussing the therapeutic uses of the chickpea, it seems worthwhile to begin with the works of Dioscorides, even though some of these have been mentioned already in the characteristics included in the De materia medica. At this particular instance, the remaining part of the material needs to be taken into consideration. Dioscorides recommended that in most cases the chickpea should be applied externally. The orobias variety, boiled and mixed with honey, was applied in the form of a cataplasm for testicular inflammations ${ }^{68}$, dermatological problems

\footnotetext{
${ }^{62}$ Aetius of Amida, Iatricorum libri, II, 200, 1-7 (the chickpea - II, 200, 5-6).

${ }^{63}$ Aetius of AmidA, Iatricorum libri, II, 234, 1-8 (the chickpea - II, 234, 2).

${ }^{64}$ Aetius of Amida, Iatricorum libri, II, 237, 1-6 (the chickpea - II, 237, 3).

${ }^{65}$ Aetius of AmidA, Iatricorum libri, II, 248, 1-6 (the chickpea - II, 248, 3).

${ }^{66}$ The chickpea was thus described as a carminative and detoxifying agent which stimulated the production of semen and boosted sexual prowess. When roasted, it was less carminative, but more difficult to digest - Paul of Aegina, Epitome, I, 79, 1, 1-15 (the chickpea - I, 79, 1, 7-9).

${ }^{67}$ The chickpea was described as being carminative, nutritious, beneficial for the stomach, diuretic, and stimulating lactation, menstruation and the production of semen. According to the author, the kriós variety was a powerful diuretic agent; he recommended a chickpea-based decoction for crushing renal calculi. The orobiai had a more powerful warming effect and were slightly bitter. The wildgrowing chickpea was believed to be more effective than the domesticated variety. See: PAUL of Aegina, Epitome, VII, 3, 5, 88-94.

${ }^{68}$ The latter work of the doctor contained statements which were formulated in a more precise manner. For testicular inflammations Dioscorides recommended chickpea flour boiled in melíkraton

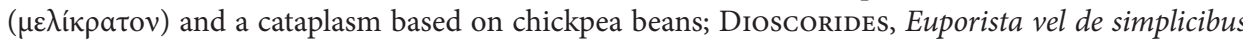
medicinis, I, 132, 1, 1-2, 10 (the chickpea - I, 132, 1, 5-6). The author noted that apart from chickpea beans the young leaves of the plant were used as a medicine. They were applied in the form of a compress in the initial stage of all kinds of inflammation - Dioscorides, Euporista vel de simplicibus medicinis, I, 136, 1, 1-2, 6 (chickpea leaves - I, 136, 2, 5-6).
} 
known as áchor (ä $\chi \omega \rho$; it manifested itself in a variety of ways of flaking off of the epidermis), various kinds of lichen, scabies ${ }^{69}$, subcutaneous warts of the myrme-

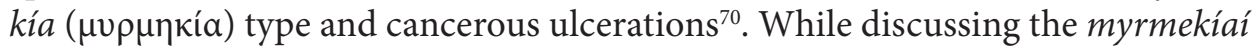

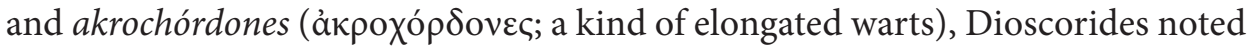
that some people would touch them with chickpea beans (one per each wart), put them in a cloth, tie it up and throw it behind their back, which was supposed to make the warts disappear ${ }^{71}$. The author, as suggested in his narrative, seems to have been sceptical about this method ${ }^{72}$.

The other memorable work of Dioscorides, the Euporista vel de simplicibus medicinis, repeats the doctrine expounded in the De materia medica, and supplements the discussion with only two pieces of additional information. The first of these indicates that the chickpea was recommended as a foodstuff beneficial for chronically affected liver ${ }^{73}$, whereas the other suggests that chickpea roots were used for compresses applied to reduce persistent swelling ${ }^{74}$.

The prescriptions recommended by Galen demonstrate that the medicinal uses of the chickpea were similar in the second half of the second century AD. The doctor of Pergamon, in keeping with the general pharmacological characteristics of the plant, recommended it for curing various conditions of the skin. Thus, he prescribed a mixture of fenugreek flour, sweet clover and a chickpea decoction

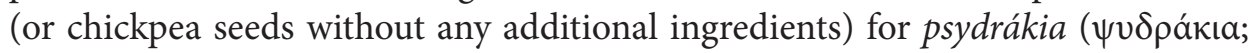

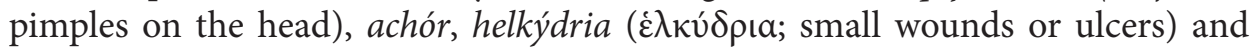
eksanthémata ( $\dot{\xi} \xi \alpha v \theta \eta \dot{\eta} \mu \alpha \tau \alpha$; that is various lesions) ${ }^{75}$. This medicament must have

\footnotetext{
${ }^{69}$ Similar skin conditions are discussed in the Euporista vel de simplicibus medicinis, where Dioscorides recommended the chickpea as a remedy for lesions, rash and other ailments generically referred to as dandruff (all affecting the skin on the head) - Dioscorides, Euporista vel de simplicibus medicinis, I, 99, 1, 1-2, 8. The treatment consisted in administering a chickpea-based decoction and a cataplasm based on boiled chickpea beans - Dioscorides, Euporista vel de simplicibus medicinis, I, $99,2,3$. In the same treatise one can find another use of the chickpea: chickpea beans boiled in vinegar were applied on wounds caused by leprosy - Dioscorides, Euporista vel de simplicibus medicinis, I, 121, 1, 1-3, 10 (the chickpea - I, 121, 2, 1-2). A decoction based on chickpea roots helped to heal

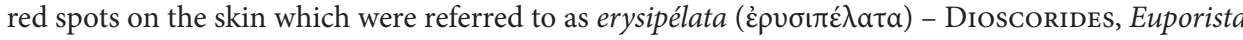
vel de simplicibus medicinis, I, 160, 1, 1-4, 7 (chickpea roots - I, 160, 4, 7).

${ }^{70}$ Dioscurides, De materia medica, II, 104, 1, 3-2, 1. The other treatise contained a recipe for a cataplasm for ulcers. It was based on boiled chickpea beans and vetches mixed with honey - DiosCORIDEs, Euporista vel de simplicibus medicinis, I, 193, 1, 1-2, 6 (the chickpea - I, 193, 1, 5-6).

${ }^{71}$ Dioscurides, De materia medica, II, 104, 2, 4-8. The therapeutic methods applied in the treatment of myrmekíai and akrochórdones are also repeated in the Euporista vel de simplicibus medicinis, I, 167, 1, 1-3, 7 (chickpea therapy - I, 167, 1, 3-2, 1).

${ }^{72}$ We refer here to the word énioi (Énioi) used by the author. It indicates the fact that this method was accepted only by some physicians or was simply used in folk medicine.

${ }^{73}$ Dioscorides, Euporista vel de simplicibus medicinis, II, 60, 1, 1-4, 6 (the chickpea - II, 60, 4, 4).

${ }^{74}$ Dioscorides, Euporista vel de simplicibus medicinis, I, 138, 1, 1-3, 8 (chickpea roots - I, 138, 3, 1).

${ }^{75}$ Galeni de compositione medicamentorum secundum locos libri X, 496, 6-497, 5, vol. XII, [in:] Claudii Galeni opera omnia, ed. C.G. KüHN, vol. XII-XIII, Lipsiae 1826-1827 (cetera: GALEN, De compositione medicamentorum secundum locos) (the chickpea - 496, 14-16, vol. XII).
} 
been applied as a cataplasm. While referring to his predecessor Archigenes (the turn of the first and the second centuries $\mathrm{AD}$ ), he quoted a number of his prescriptions, including a medicine used for dark blemishes, particularly around the eyes: hypópia $(\dot{v} \pi \dot{\omega} \pi \mathrm{i})$. The orobias variety was mentioned as a remedy for this condition; it should have been soaked in wine, mashed and applied as a compress ${ }^{76}$.

The doctor of Pergamon also left a fair amount of information about the treatment of jaundice with the use of the chickpea. He included in his account a diuretic prescription found in Asclepiades (the turn of the second and the first century $\mathrm{BC}$ ), but apparently attributable to Nikeratos. It was administered to people suffering from jaundice, as is illustrated by the fact that the cure was described in a fairly long fragment of the De compositione medicamentorum secundum locos devoted to the treatment of this particular disease. It was composed of dried chickpea beans, rosemary, dill and wild asparagus roots. The ingredients were first boiled in water and then drained off. The decoction was administered as a beverage to quench thirst, also when the sick suffered from high fever. If the fever did not complicate the process of treatment, the medicine was mixed with some diluted wine $e^{77}$. Another prescription documented by Galen recommended using dry chickpea beans, a bunch of adiantum (that is, the maidenhair fern) and the same amount of wild asparagus. It is implied that it was prepared and administered in a similar way to that described above $e^{78}$. Archigenes also prescribed a different medicament for jaundice, namely soaked chickpea beans of the orobias variety exposed to the sun. The obtained liquid was administered as a beverage, whereas the beans were eaten for two consecutive days, one portion in the morning and the other in the evening. Having completed this procedure, the patients were told to drink melikraton ( $\mu \varepsilon \lambda$ íkратоv) with an admixture of wormwood for three days ${ }^{79}$.

Among the many uses of the plant, the doctor of Pergamon mentioned an intriguing and untypical dental practice. While discussing the ways of extracting molar teeth, he prescribed a mixture of chickpea flour and garden spurge juice. It was to be applied on the tooth and covered with ivy leaves. An hour later, the extraction could begin, which apparently, according to Galen, would not lead to any major problems. The same procedure could be used for extracting other types of teeth. It also included the use of the ointment called keroté (

\footnotetext{
${ }^{76}$ Galen, De compositione medicamentorum secundum locos, 807, 14-814, 15, vol. XII (the quoted passage - 813, 16-814, 1, vol. XII; the chickpea - 814, 1, vol. XII).

${ }^{77}$ Galen, De compositione medicamentorum secundum locos, 231, 15-233, 2, vol. XIII (the quoted recipe - 232, 13-18, vol. XIII; the chickpea - 232, 14, vol. XIII).

${ }^{78}$ The quoted recipe - GALEN, De compositione medicamentorum secundum locos, 232, 18-233, 2, vol. XIII (the chickpea - 232, 18, vol. XIII).

${ }^{79}$ Galen, De compositione medicamentorum secundum locos, 234, 4-236, 14, vol. XIII (the quoted recipe -236, 5-8, vol. XIII; the chickpea - 236, 5, vol. XIII).

${ }^{80}$ Galen, De compositione medicamentorum secundum locos, 883, 6-10, vol. XII (chickpea flour $-883,6$, vol. XII).
} 
The Collectiones medicae by Oribasius, likewise his Eclogae medicamentorum, contain only a few prescriptions for the therapeutic use of the chickpea. Nevertheless, in conjunction with the dietary and pharmacological characteristics discussed above, they allow to observe that the plant was still used in the treatment of analogous conditions. Oribasius preserved the formula for this medicament in the form of a compress referred to by this author as epiplasma ( $\dot{\varepsilon} \pi i \pi \lambda \alpha \sigma \mu \alpha)$ used in this kind of hydrops. It was made of chopped rue leaves mixed with boiled honey and chickpea flour ${ }^{81}$.

Oribasius analysed the writings of Galen and in the Collectiones medicae presented a selection of his doctrine concerning the treatment of scleroses and swellings. Among other things, he quoted the already mentioned statements of the doctor of Pergamon on the effectiveness of the chickpea as a remedy for mumps and testicular inflammations (presumably, it involved using therapeutic softeningdiaphoretic compresses) ${ }^{82}$. The treatise Eclogae medicamentorum testifies that still in the fourth century the plant was often applied in the treatment of the latter condition. In the chapter dedicated to the therapy of scrotal hernia, the doctor referred to healing testicular inflammations with chickpea flour mixed with boiled melikraton. The mixture must have been applied as a compress on the glands, hardened (as we know from other sources) by the inflammation ${ }^{83}$.

We can also infer from the writings of Oribasius that the chickpea was a very popular remedy in the treatment of jaundice. A decoction based on the white variety was administered as a beverage to the sick ${ }^{84}$. Another medicament was prepared by boiling chickpeas with a bunch of dill, until the ingredients were completely soft. The plants were then removed and the decoction was mixed with oinómeli (oivó $\mu \varepsilon \lambda_{\mathrm{l}}$ ) and given to the patient ${ }^{85}$. The Eclogae medicamentorum recommend that women having irregular periods should eat (presumably boiled) chickpea beans ${ }^{86}$; this prescription can also be find in both earlier and later medical writings.

The medical procedures described in the first half of the sixth century demonstrate that the chickpea was still used in much the same way as previously. It is worth noting, however, that the work of Aetius of Amida preserves a particularly significant number of methods of treatment based on the therapeutic qualities attributed to this plant. As illustrated in the Iatricorum libri, erébinthos was still believed to be a very effective aphrodisiac: Book XI includes references to

\footnotetext{
${ }^{81}$ Oribasius, Collectiones medicae, IX, 39, 1, 1-2, 3 (chickpea flour - IX, 39, 2, 3).

${ }^{82}$ Oribasius, Collectiones medicae, XLIV, 27, 1, 1-15, 6 (the chickpea as an anti-inflammatory agent, see - XLIV, 27, 6, 1-20).

${ }^{83}$ Oribasii eclogae medicamentorum, 84, 1, 1-133, [in:] Oribasii collectionum medicarum reliquiae, ed. I. RAEDER, vol. IV, Lipsiae-Berolini 1933 (cetera: OrIbasius, Eclogae medicamentorum) (testicular inflammations - 84, 11, 1-5; a medicine with the chickpea - 84, 11, 3-4).

${ }^{84}$ Oribasius, Eclogae medicamentorum, 50, 1, 1-12, 10 (the chickpea - 50, 4, 3).

${ }^{85}$ Oribasius, Eclogae medicamentorum, 50, 9, 1-2.

${ }^{86}$ Oribasius, Eclogae medicamentorum, 146, 1, 1-17, 3 (the chickpea - 146, 14, 9).
} 
the writings of Rufus of Ephesus on the factors increasing sexual prowess (the chickpea is mentioned there as one of the particularly important foodstuffs in this respect $)^{87}$. The author repeats this suggestion in the same book and explains that people suffering from problems with potency should include the chickpea in their diet on account of its warming and carminative properties ${ }^{88}$.

Aetius of Amida discussed the detoxifying qualities of the plant, which had been described previously by earlier medical writers, and included a decoction based on the chickpea as a powerful laxative used to empty the small intestine ${ }^{89}$. Its anti-inflammatory properties are also mentioned by the author of Iatricorum libri, who made references to the practice of using a decoction of the white chickpea as a remedy for chronic hepatic inflammations ${ }^{90}$. For the urinary system malfunctions, he recommended a decoction based on the black (that is kriós) chickpea as a powerful medicine from the tmetiká ( $\tau \mu \eta \tau \iota k a ́)$ group, which was a highly effective remedy for renal calculi (it also helped to excrete the stones with urine) ${ }^{91}$. He prescribed the same medicament (but with an admixture of thymes) for problems with the bladder and warned that this medicine had a powerful and nearly immediate therapeutic effect ${ }^{92}$. When seasoned with pepper and rue, it induced menstruation ${ }^{93}$; without any additional components, it was administered to women who had low body temperature because of their temperament, which caused irregular periods ${ }^{94}$. The author of the Iatricorum libri promoted the use of the plant as a remedy for speech organ disorders. For problems with the throat, which might potentially lead to loss of voice, he recommended using a decoction based on the chickpea mixed with styrax. Aetius of Amida borrowed this information from Antonius Musa (first century BC) ${ }^{95}$.

His work contains a number of prescriptions for the external use of the plant. For instance, the author recommended using a cataplasm for healing wounds caused by bloodletting. It was prepared on the basis of chickpea flour (or an analogous product based on fenugreek, barley and broad beans) boiled in oinelaion (oivelaĩov - a mixture of water, wine, wine must and rose oil). The compresses were warmed up and applied on skin (the doctor recommended that they should be changed frequently $)^{96}$. He also mentioned cataplasms prepared on the basis

\footnotetext{
${ }^{87}$ Aetius of Amida, Iatricorum libri, III, 8, 1-71 (the chickpea - III, 8, 57).

${ }^{88}$ Aetius of Amida, Iatricorum libri, XI, 35, 1-18 (the chickpea - XI, 35, 8).

${ }^{89}$ Aetius of AmidA, Iatricorum libri, III, 145, 1-18 (the chickpea - III, 145, 3).

${ }^{90}$ Aetius of Amida, Iatricorum libri, III, 146, 1-7 (the chickpea - III, 146, 4-5).

${ }^{91}$ Aetius of Amida, Iatricorum libri, III, 149, 1-9 (the chickpea - III, 149, 3). Aetius of Amida also observed that a lentils-based decoction was an effective remedy for renal calculi - AETIUs of AMIDA, Iatricorum libri, XI, 5, 1-99 (the chickpea - XI, 5, 50).

${ }_{92}$ Aetius of Amida, Iatricorum libri, XI, 22, 25-26.

${ }^{93}$ Aetius of AmidA, Iatricorum libri, III, 154, 1-18 (the chickpea - III, 154, 4).

${ }^{94}$ Aetius of AmidA, Iatricorum libri, XVI, 52, 1-53 (the chickpea - XVI, 52, 22).

${ }^{95}$ Aetius of Amida, Iatricorum libri, VIII, 56, 1-38 (the chickpea - VIII, 56, 3).

${ }^{96}$ Aetius of AmidA, Iatricorum libri, XII, 26, 1-15 (the chickpea - XII, 26, 10).
} 
of the same kind of flour, but mixed with some melikraton ( $\mu \varepsilon \lambda$ íkpatov) or pork fat $^{97}$. For people suffering from excessive amount of phlegm, the doctor prescribed compresses based on chickpea and birthwort ${ }^{98}$. Another medicament in the form of a compress was applied on painless lumps and was made of maidenhair fern, nettle, althaea and other plants mixed with chickpea flour, bread and (vegetable or animal) fats ${ }^{99}$. In the sixth century, the plant was also used as a remedy for various skin conditions. For instance, Aetius recommended using it to remove dandruff and similar ailments, with or without exudations. The treatment was preceded with detoxifying the whole body with appropriate medicaments (such as whey) and bloodletting (if necessary). The text implies using a wide range of medicines, including some of the most simple nature such as a compress made of boiled chickpea beans and a chickpea decoction used for rinsing the skin on the head ${ }^{100}$.

Aetius of Amida, in addition to the dermatological uses mentioned above, included several Recipes for cosmetics. One of these was called stílboma prosópou ( $\sigma \tau i \lambda \beta \omega \mu \alpha \pi \rho \sigma \dot{\prime} \pi \mathrm{r})$ and was used to brighten the skin on the face and give it a faint blush ${ }^{101}$. It was made of ground vetch, broad beans, lupine, barley, chickpeas, durum wheat and narcissus bulbs. All ingredients were crushed, thoroughly sifted and mixed with egg white. The mixture was then formed into pills and dried in a shady place. It was diluted in water and applied on the skin after bath ${ }^{102}$. Dark colourings were treated with a peeling made of frankincense, thoroughly rinsed white lead, iron oxide rinsed in a decoction of the white chickpea, starch, filings of white marble, mastix, potassium salpetre, sepia shells, Gallic soap and egg white ${ }^{103}$. A significant part of Book VIII of the Iatricorum libri is devoted to cosmetic recipes borrowed from Crito (second century $\mathrm{AD}$ ) for protecting the skin from overheating. One of these was made of iron oxide thoroughly bleached in the sun in a chickpea decoction, Nepalese cardamom, kassía cinnamon, spikenard leaves, alum and iris ${ }^{104}$. Book IV contains a detailed recipe for removing unwanted hair. It was made of rice, peas, chickpeas, barley, quicklime, arsenic trioxide, myrrh, mastix and balm tree resin ${ }^{105}$. According to the author, the basic ingredients (rice, peas and chickpeas) were boiled and then mixed with heated quicklime

\footnotetext{
${ }^{97}$ Aetius of Amida, Iatricorum libri, XII, 30, 1-24 (the chickpea - XII, 30, 18).

${ }_{98}$ Aetius of Amida, Iatricorum libri, XII, 37, 1-56 (the chickpea - XII, 37, 33).

${ }^{99}$ Aetius of AmidA, Iatricorum libri, XII, 48, 1-77 (the quoted passage - XII, 48, 32-41; the chickpea - XII, 48, 35).

${ }^{100}$ Aetius of Amida, Iatricorum libri, VI, 68, 1-95 (the chickpea - VI, 68, 37).

${ }^{101}$ Perhaps the issue at stake was to protect oneself from the burning sunlight and hence to preserve a fair complexion.

${ }_{102}$ Aetius of Amida, Iatricorum libri, VIII, 6, 17-22 (the chickpea - VIII, 6, 18).

${ }^{103}$ Aetius of Amida, Iatricorum libri, VIII, 6, 63-68 (the chickpea - VIII, 6, 65).

${ }^{104}$ Aetius of AmidA, Iatricorum libri, VIII, 7, 1-44 (the quoted passage - VIII, 7, 11-14; the chickpea - VIII, 7, 12).

${ }^{105}$ Balsamodendron opobalsamum Kunth.
} 
and arsenic trioxide. The myrrh, mastix and balm tree resin must have been used to give a pleasant scent to the mixture ${ }^{106}$.

Book XVI in its turn preserved a recipe which is both medicinal and culinary, namely a therapeutic garum used to intensify digestive processes and made of water, salt, black chickpeas, amanitai mushrooms and dried figs. All ingredients were mixed and left to mature. After some time, the mixture was sifted and stored $^{107}$.

The medical encyclopaedia of Paul of Aegina indicates that the chickpea continued to be used in the traditional way at the turn of the sixth and the seventh centuries. One of the cosmetological remarks contained in his work was an observation that the pallor of the face disappeared owing to joy and an appropriate diet, which, as he recommended, should include green chickpeas ${ }^{108}$. As far as the sui generis early Byzantine sexology is concerned, Paul of Aegina proved to be yet another medical writer who incorporated the already quoted reflections of Rufus of Ephesus which emphasized the role of the chickpea in the diet recommended for people wishing to improve their potency ${ }^{109}$. In addition to that, he described (in Book III) a stimulant made of chickpea beans, black pine, rocket, pepper and honey. The ingredients were ground, mixed with wine and administered as a beverage ${ }^{110}$.

The doctor of Aegina also discussed using the chickpea in the treatment of testicular inflammations ${ }^{111}$. Some details included in his encyclopaedia had not been mentioned by earlier authors. There is for instance a recipe for a cataplasm made of henbane leaves mixed with wheat of chickpea flour, which was applied on the inflamed glands in acute orchitis ${ }^{112}$. Another medicine of this sort was more complicated as the recipe involved using pitted raisins, boiled chickpea beans, cumin, sulphur, soda and resin, all crushed and mixed with honey ${ }^{113}$. Still in the seventh century the chickpea was used as a diuretic agent. It was also recommended for inducing menstruation ${ }^{114}$. Paul of Aegina prescribed the kriós variety as a remedy for kidney stones; he provided a detailed explanation of the etiology of the disease and of the reasons for the use of this plant ${ }^{115}$. His encyclopaedia contains also

\footnotetext{
${ }^{106}$ Aetius of AmidA, Iatricorum libri, VI, 64, 1-23 (the quoted passage - VI, 64, 9-14; the chickpea - VI, 64, 10).

${ }^{107}$ Aetius of Amida, Iatricorum libri, XVI, 141, 1-3 (the chickpea - XVI, 141, 1-2).

${ }^{108}$ Paul of Aegina, Epitome, I, 27, 1, 1-9 (the chickpea - I, 27, 1, 2-3).

${ }^{109}$ Paul of Aegina, Epitome, I, 35, 1, 1-34 (the chickpea - I, 35, 1, 19).

${ }^{110}$ Paul of Aegina, Epitome, III, 58, 1, 1-18 (the quoted passage - III, 58, 1, 13-14; the chickpea - III, 58, 1, 13).

${ }^{111}$ Paul of Aegina, Epitome, III, 54, 1, 1-2, 19.

112 Paul of Aegina, Epitome, III, 54, 2, 8-10.

113 Paul of Aegina, Epitome, III, 54, 2, 12-15.

${ }^{114}$ Paul of Aegina, Epitome, III, 61, 1, 1-5, 17 (the chickpea - I, 61, 5, 10).

${ }^{115}$ Dense fluids turned solid owing to the heat characteristics of the kidneys and the bladder. Thus the treatment was based on cutting substances which did not increase body temperature, PAUL
} 


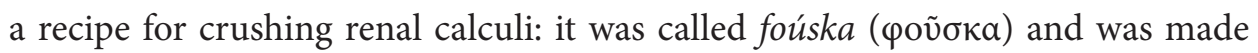
of a black chickpea decoction, asparagus roots, celery and maidenhair fern. Mixed with wine vinegar, it was administered to patients during hot bath ${ }^{116}$.

Other uses mentioned by the author included using chickpea flour for cataplasms applied on painful inflammations. If the pain was moderate, the cataplasms were made of green cabbage and celery, but when the situation deteriorated, the inflamed spot was coated with a medicine made of fenugreek flour, darnel and chickpeas mixed with melíkraton (or wine) and a tinge of alkanet (or spikenard) oil $^{117}$. The chickpea also appeared on the list of compresses effective in the treatment of scabies ${ }^{118}$ and lichen planus ${ }^{119}$. It should also be noted that cataplasms made of chickpea flour (or other flours, made of, for example, broad beans, lupine, barley or barley groats) were used as a remedy for inflamed lesions of hard tissues $^{120}$. The physician observed that a chickpea decoction and chickpea beans were believed to have a detoxifying effect and could be used as an antidote for unsafe drinking water ${ }^{121}$. There was also a chickpea-based antidote for spider bites of the falángia ( $\varphi \propto \lambda a ́ \gamma \gamma \iota \alpha)$ type: a decoction based on wild-growing chickpeas mixed with wine was administered during bath ${ }^{122}$.

\section{Conclusions}

The first conclusion to be drawn from the material presented above is that the ancient and early Byzantine physicians had a profound knowledge about the chickpea. They all regarded the plant as both a fármakon (a therapeutic substance) and a foodstuff, which is typical of the medical writings of the time on account of the established doctrine.

Secondly, it has to be concluded that the chickpea was one of the most basic foodstuffs, given that it was given so much attention by the authors of theoretical treatises since the fourth century, who consistently indicated the same dietary characteristics of the plant. The theory concerning its role in the diet evolved into a fully developed form only in the first century, as is illustrated in the work of Dioscorides. Galen, who lived in the second century, did not modify these

of Aegina, Epitome, III, 45, 1, 1-3, 22 (explanations concerning the nature of renal calculi and the expectations related to therapeutic substances - III, 45, 2, 6-17; the chickpea - III, 45, 2, 12-13).

${ }_{116}$ Paul of Aegina, Epitome, VII, 11, 48, 1-12 (the recipe - VII, 11, 48, 7-10; the chickpea - VII, $11,48,7)$.

${ }_{117}^{11}$ Paul of Aegina, Epitome, III, 78, 1, 1-19, 22 (the quoted passage - III, 78, 15, 1-13; the chickpea - III, 78, 15, 4).

${ }^{118}$ Paul of Aegina, Epitome, IV, 2, 3, 1-4 (the chickpea - IV, 2, 3, 3).

${ }^{119}$ Paul of Aegina, Epitome, IV, 3, 1, 1-14 (the chickpea - IV, 3, 1, 4).

${ }^{120}$ Paul of Aegina, Epitome, IV, 54, 1, 1-10, 5 (the quoted passage - IV, 54, 4, 11-16; the chickpea - IV, 54, 4, 13).

${ }^{121}$ Paul of Aegina, Epitome, I, 50, 1, 1-41 (the chickpea - I, 50, 1, 38-39).

${ }^{122}$ Paul of Aegina, Epitome, V, 6, 1, 1-2, 12 (the chickpea - V, 6, 2, 7-8). 
observations. The foundational doctrine of these two physicians became part of the medical encyclopaedias of the early Byzantine period, which preserved the ancient theories on the subject and did not create a separate body of knowledge.

Thirdly, medical writings may serve as a proof that the chickpea remained a key element in the Mediterranean diet throughout the period from the fourth century $\mathrm{BC}$ to the seventh century AD. Had it been otherwise, the physicians would not have paid so much attention to this plant. The analysed material demonstrates the use of the same basic varieties of the erébinthos throughout the period, even though some local variants were also identified, as illustrated by the remark by Diocles of Carystus. The consistency of the data also suggests that the scale and methods of cultivation of this plant remained unchanged. The culinary uses of the chickpea must also have been the same throughout the period, given that the writers discussed similar uses of the plant as a foodstuff. This means, among other things, that it was used primarily in boiled dishes, seasoned with some local herbal additives ${ }^{123}$.

Fourthly, the source material presented above demonstrates that the medicinal properties of the chickpea and its therapeutic use were discussed by Greek physicians as early as in the fourth century BC. It seems that it was a readily accessible medicament and thus used in therapy also by those who could not afford more sophisticated medicines. Symptomatically, it was only Aetius of Amida who mentioned the chickpea in the context of imported medicinal ingredients, which must have been more expensive (see the passage of the Iatricorum libri based on the work of Crito) ${ }^{124}$. These remarks, however, referred only to cosmetics, not to the therapeutic uses. The luxury additives were supposed to give a distinctly pleasant smell to these specifics and as such they served as aromatic ingredients rather than fármaka in the strict sense.

The presented material also illustrates the fact that a significant number of medicinal recipes which involved using the chickpea were formulated between the second century $\mathrm{BC}$ and the second century $\mathrm{AD}$. Byzantine physicians avidly used these formulas in their practice, but failed to develop them in a significantly innovative way.

Finally, it has to be noted that the list of ailments treated with various chickpea specifics was fairly long and remained roughly the same throughout the whole period under scrutiny. Its first exhaustive version can be found in the writings of Dioscorides, who drew attention to the use of the plant in the therapies of urinary system malfunctions (particularly renal calculi). In addition to that, the chickpea was used for jaundice, hepatic problems, and cutaneous conditions (for instance, it reduced various kinds of edema). The medicines produced on the

\footnotetext{
${ }^{123}$ See the remark concerning rue as an additive reducing the carminative effect of the chickpea. These include for instance Nepalese cardamom, kassía cinnamon, spikenard leaves, myrrh and balm tree resin.

${ }^{124} \mathrm{Cf}$. information on rue.
} 
basis of the plant often took the form of a compress, whereas a decoction made of chickpea beans was applied in internal use. The surviving medical writings make it possible to conclude that the chickpea was believed to be a highly effective medicine and as such worthy of cultivation, which only testifies to the general popularity of the plant.

\section{Bibliography}

\section{Sources}

Aetii Amideni libri medicinales I-VIII, ed. A. Olivieri, Lipsiae-Berolini 1935-1950.

Atenajos, Uczta mędrców, trans., ed. K. Bartol, J. Danielewicz, Poznań 2010.

Athenaei Naucratitae dipnosophistarum libri XV, rec. G. KAIBEL, vol. I-III, Lipsiae-Berolini 18871890.

Galeni De alimentorum facultatibus libri III, [in:] Claudii Galeni opera omnia, ed. D.C.G. KüHN, vol. VI, Lipsiae 1823.

Galeni de compositione medicamentorum secundum locos libri X, [in:] Claudii Galeni opera omnia, ed. C.G. KüHN, vol. XII-XIII, Lipsiae 1826-1827.

Galeni De simplicium medicamentorum temperamentis ac facultatibus libri XI, [in:] Claudii Galeni opera omnia, ed. D.C.G. KüHN, vol. XI-XII, Lipsiae 1826-1827.

Hippocratis de diaeta, ed. R. Joly, S. ByL, Berlin 2003.

Oribasii collectionum medicarum reliquiae, ed. I. RAEDER, vol. I-IV, Lipsiae-Berolini 1928-1933.

Oribasii eclogae medicamentorum, [in:] Oribasii collectionum medicarum reliquiae, ed. I. RAEDER, vol. IV, Lipsiae-Berolini 1933.

Paulus Aegineta, ed. I.L. Heiberg, vol. I-II, Lipsiae-Berolini 1921-1924.

Pedanii Dioscuridis Anazarbei De materia medica libri quinque, ed. M. Wellmann, vol. I-III, Berlin 1907-1914.

Pedanii Dioscuridis Anazarbei Euporista vel de simplicibus medicinis, [in:] Pedanii Dioscuridis Anazarbei De materia medica libri quinque, ed. M. Wellmann, vol. III, Berlin 1914.

\section{Secondary literature}

ALсоск J.P., Food in the ancient world, Westport-London 2006.

Amouretti M.-C., Villes et campagnes grecques, [in:] Histoire de l'alimentation, ed. J.-L. Flandrin, M. Montanari, Paris 1996, p. 133-150.

Anagnostakis I., Pallikaria of lentils. The "brave boys" of beans, [in:] Flavours and delights. Tastes and pleasures of ancient and Byzantine cuisine, ed. I. AnAgnostakis, Athens 2013, p. 133-137.

ANAGNOSTAKIS I., "The raw and the cooked": ways of cooking and serving food in Byzantium, [in:] Flavours and delights. Tastes and pleasures of ancient and Byzantine cuisine, ed. I. ANAGNostakis, Athens 2013, p. 175-181.

ANDRÉ J., L'alimentation et la cuisine à Rome, Paris 1961. 
Bourbou C., Health and disease in Byzantine Crete ( $7^{\text {th }}-12^{\text {th }}$ centuries AD), Farnham-Burlington 2010.

Braudel F., La Méditerranée et le monde méditerranéen à l'époque de Philippe II, vol. I-II, Paris 1966.

Bresciani E., Nourritures et boissons de l'Égypte ancienne, [in:] Histoire de l'alimentation, ed. J.-L. FlaNDRIN, M. Montanari, Paris 1996, p. 61-72.

Cheynet J.-C., La valeur marchande des produits alimentaires dans l'Empire byzantin, [in:] Byzantinon diatrohi kai mageireiai. Praktika imeridas "Peri tis diatrophis sto Byzantio". Food and cooking in Byzantium. Proceedings of the symposium "On food in Byzantium". Thessaloniki Museum of Byzantine Culture 4 November 2001, ed. D.D. Papanikola-Bakirtzi, Athens 2005, p. 31-45.

DALBy A., Flavours of Byzantium, Totnes 2003.

DALBY A., Food in the ancient world from A to Z, London-New York 2003.

Dalby A., The flavours of classical Greece, [in:] Flavours and delights. Tastes and pleasures of ancient and Byzantine cuisine, ed. I. Anagnostakis, Athens 2013, p. 17-35.

DAR P., Food and archeology in Romano-Byzantine Palestine, [in:] Food in antiquity, ed. J. Wilkins, D. Harvey, M. Dobson, Exeter 1995, p. 326-335.

Flint-Hamilton K.B., Legumes in ancient Greece and Rome: food, medicine or poison, "Hesperia. The Journal of the American School of Classical Studies at Athens" 68, 1999, p. 371-385.

Foxhall L., Forbes H.A., Sitomereia: the role of grain as staple food in classical antiquity, "Chiron. Mitteilungen der Kommission für alte Geschichte und Epigraphik des Deutschen Archäologischen Instituts" 12, 1982, p. 41-90.

GARNSEY P., Food and society in classical antiquity, Cambridge 2002.

Grottanelli C., La viande et ses rites, [in:] Histoire de l'alimentation, ed. J.-L. Flandrin, M. MonTANARI, Paris 1996, p. 117-132.

KISLINGER E., Les chrétiens d'Orient: règles et réalités alimentaires dans le monde byzantin, [in:] Histoire de l'alimentation, ed. J.-L. Flandrin, M. Montanari, Paris 1996, p. 325-344.

KODER J., I kathemerini diatrophi sto Byzantio me basi tis piges, [in:] Byzantinon diatrohi kai..., p. 17-30.

Koder J., Stew and salted meat - opulent normality in the diet of every day?, [in:] Eat, drink and be merry (Luke 12:19). Food and wine in Byzantium. In honour of Professor A.A.M. Bryer, ed. L. BRUBAKER, K. LinARdou, Aldershot 2007, p. 59-72.

Kокоszко M., Smaki Konstantynopola, [in:] Konstantynopol - Nowy Rzym. Miasto i ludzie w okresie wczesnobizantyńskim, ed. M.J. LeszKa, T. WolińsKa, Warszawa 2011, p. 471-575.

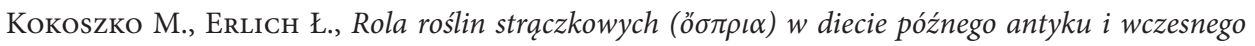
Bizancjum (IV-VII w.) na podstawie wybranych źródeł, "Zeszyty Wiejskie" 17, 2012, p. 8-18.

Кокоszко M., RzeźNicka Z., Jagusiak K., Rola roślin strączkowych (óspria) w świetle źródeł medycznych pomiędzy II a VII w., [in:] Dietetyka i sztuka kulinarna antyku i wczesnego Bizancjum (II-VII w.), vol. II, Pokarm dla ciała i ducha, ed. M. Кокоszко, Łódź 2014, p. 67-75.

Koкoszko M., Dybaєa J., Jagusiak K., Rzeźnicka Z., Dieta mnichów syryjskich. Komentarz do terminu ospria (ö $\sigma \pi \rho \iota \alpha)$ w Historia religiosa Teodoreta $z$ Cyru, "Biblica et Patristica Thoruniensia" 7, 2014, p. 115-143.

Кокоszкo M., DybaŁa J., Jagusiak K., Rzeźnicka Z., Dieta monastyczna w świetle nauki medycznej. Teodoret z Cyru i medycy o soczewicy, "Vox Patrum" 34, 2014, p. 297-329.

Koukoules Pн., Byzantinon bios kai politismos, vol. V, Hai trofai kai ta pota..., Athènes 1952. 


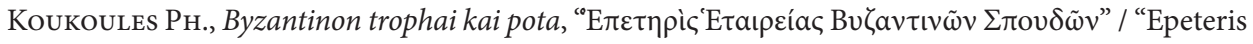
tes Hetaireias Byzantinon Spoudon” 17, 1941, p. 3-112.

Koukoules Pн., Everyday food in the middle Byzantine period, [in:] Flavours and delights. Tastes and pleasures of ancient and Byzantine cuisine, ed. I. Anagnostakis, Athens 2013, p. 139-155.

Nutton V., Galen and the traveler's fare, [in:] Food in antiquity, ed. J. Wilkins, D. Harvey, M. Dobson, Exeter 1995, p. 359-370.

Perlès C., Les stratégies alimentaires dans les temps préhistoriques, [in:] Histoire de l'alimentation, ed. J.-L. Flandrin, M. Montanari, Paris 1996, p. 29-46.

Rautman M.L., The daily life in the Byzantine Empire, Westport-Oxford 2006.

Sassatelli G., L'alimentation des Étrusques, [in:] Histoire de l'alimentation, ed. J.-L. Flandrin, M. Montanari, Paris 1996, p. 183-195.

Spanò Giammellaro A., Les Phéniciens et les Carthaginois, [in:] Histoire de l'alimentation, ed. J.-L. Flandrin, M. Montanari, Paris 1996, p. 85-99.

STATHAKopoulos D., Between the field and the plate: how agricultural products were processed into food, [in:] Eat, drink and be merry (Luke 12:19). Food and wine in Byzantium. In honour of Professor A.A.M. Bryer, ed. L. Brubaker, K. Linardou, Aldershot 2007, p. 27-38.

Wilkins J.M., HiLl P., Food in the ancient world, Oxford 2006.

\begin{abstract}
Leguminous plants were a crucially important element in the Mediterranean diet, and, as such, these plants were second only to cereals. It is also important to note that according to medical writings preserved from antiquity and the early Byzantine period they were considered to be an accessible source of substances which could be applied in therapeutics. One of the most commonly mentioned legumes was the chickpea.
\end{abstract}

The source material demonstrates that the medicinal properties of the chickpea and its therapeutic use were discussed by Greek physicians as early as in the fourth century BC. It seems that the plant was a readily accessible medicament and thus used in therapy also by those who could not afford costly medicines. The authors argue, however, that the medical theory concerning its role in therapeutics evolved into a fully developed form only in the first century AD (thanks to Dioscorides) and was not modified by Galen. The doctrine of these two physicians became part of the medical encyclopaedias of the early Byzantine period. The presented material also illustrates the fact that a significant number of medicinal Recipes which involved using the chickpea were formulated between the second century BC and the second century AD. Byzantine physicians avidly used these formulas in their practice, but failed to develop them in a significantly innovative way. The surviving medical writings make it possible to conclude that the chickpea was believed to be a highly effective medicine and as such worthy of cultivation, which only testifies to the general popularity of the plant.

Medical writings may serve as a proof that the chickpea remained a key element in the Mediterranean diet throughout the period from the fourth century BC to the seventh century AD. The analysed material demonstrates the use of the same basic varieties of the erébinthos throughout the period, even though some local variants were also identified. The consistency of the data also suggests that the scale and methods of cultivation of this plant remained unchanged. The culinary uses of the chickpea must also have been the same throughout the period, given that the writers discussed similar uses of the plant as a foodstuff. 
Keywords: food history; ancient medicine; Byzantine medicine; the chickpea as a medicament; Diocles of Carystus; Dioscorides; Galen; Aetius of Amida; Paul of Aegina; Athenaeus of Naucratis

Maciej Kokoszko

Uniwersytet Łódzki Wydział Filozoficzno-Historyczny Instytut Historii Katedra Historii Bizancjum ul. Kamińskiego 27 a 90-219 Łódź, Polska/Poland mkokoszko@komanador.pl

Krzysztof Jagusiak

Centrum Badań nad Historią i Kulturą Basenu Morza Śródziemnego i Europy Południowo-Wschodniej im. prof. Waldemara Cerana, Ceraneum ul. Matejki 32/38, sala 319 90-237 Łódź, Polska/Poland krzysztof_jagusiak@o2.pl

Jolanta Dybała

Uniwersytet Jana Kochanowskiego Filia w Piotrkowie Trybunalskim, Biblioteka ul. J. Słowackiego 114/118 97-300 Piotrków Trybunalski, Polska/Poland j.dybala@vp.pl 